\title{
Znikający punkt zwrotny. Piotra Chmielowskiego kłopoty z periodyzacją „najnowszej literatury polskiej”
}

Wydawać by się mogło, że roli Piotra Chmielowskiego w dziejach refleksji nad literaturą polską okresu pozytywizmu nie sposób przecenić. Jego ogłoszony w 1881 roku Zarys literatury polskiej z ostatnich lat szesnastu stanowił bowiem swoistą legitymizację „nowego okresu” i - jak pisze Henryk Markiewicz - właśnie „za sprawą" Piotra Chmielowskiego jako autora Zarysu nastąpiło „utworzenie pojęcia » przełom pozytywistyczny « i powiązanie go z datą klęski powstania styczniowego" ". Szkopuł tkwi jednak w użytym tu nieprzypadkowo sformułowaniu „za sprawą”, jako że sam Chmielowski nie określa zajmującej go dziejowej zmiany mianem „przełomu” ani nie wiąże jej wprost z upadkiem powstania. Uczynią to dopiero recenzenci Zarysu, pisząc otwarcie o „smutnym doświadczeniu ostatniego zbrojnego porywu” (Aleksander Świętochowski) i o przebytym „ciężkim kataklizmie" (Józef Kotarbiński) oraz wprowadzając w obręb dyskur$\mathrm{su}$ - notabene w kontekście polemicznym - kluczowe z późniejszej perspektywy słowo „przełom” (Henryk Sienkiewicz) ${ }^{2}$. Powściągliwość Chmielowskiego, jeśli chodzi o bezpośrednie odniesienia do sytuacji politycznej, można oczywiście tłumaczyć względem na rosyjską cenzurę, ostrzejszą wobec książek niż wobec publikacji prasowych. W świetle otwierającego $\mathrm{Za}$ rys porównania „stanu rzeczy po roku 1864” z ,analogicznym stanem po roku 1831" powiązanie tej pierwszej daty nie z klęską kolejnego powstania, lecz z przeprowadzonym na mocy carskich ukazów uwłaszczeniem chłopów dałoby się nawet odczytać jako przykład „języka ezopowego” - w 1831 nie dokonał się wszak żaden podobny „wielki przewrót w stosunkach ekonomicznych

${ }^{\text {I }}$ H. Markiewicz, Spór o przetom pozytywistyczny, w: Literatura i historia, Kraków 1994, s. 36. Pierwodruk: „Teksty Drugie” 1990, nr 5/6.

${ }^{2}$ Zob. ibidem, s. 36-37, 42. 
i społecznych" 3 . Pytanie tylko, czy zgłoszona przez Chmielowskiego propozycja periodyzacyjna rzeczywiście wymagała aż tak daleko posuniętej ostrożności?

Rok 1864 nie był dla Rosjan kamieniem obrazy niezależnie od tego, czy oznaczał „wyzwolenie polskiego chłopa”, czy „uśmierzenie polskiego buntu" (pierwsze służyło wszak drugiemu). Co innego data wybuchu powstania. Dobrą ilustrację stanowić może fragment biografii Fiodora Dostojewskiego, wydanej w roku 1883, w którym Orest Miller tak tłumaczył stanowisko pisarza wobec „polskiego powstania 1863 r.” (podkr. - M.W.):

Polskie powstanie [...] wydało mu się szyderstwem nad całym ludem rosyjskim, który doczekał się wreszcie Cara Wyzwoliciela. [...] przesiąknięte było starodawnym jaśniewielmożnym duchem pogardy dla chłopstwa. Nie do Polski czuł odrazę Dostojewski, nie do ludu polskiego, któremu ostatecznie tenże cesarz rosyjski przydzielił ziemię; napełniał go oburzeniem [...] duch polskiej szlachty [...]. Nienawidził tych staropolskich tendencji, podobnie jak [...] wielu spośród uczciwych, bezinteresownych, oddanych polskich patriotów ${ }^{4}$.

Z takiego punktu widzenia słowa Chmielowskiego o reformie włościańskiej, będącej „życzeniem ludzi postępowych już od wieku niemal", a urzeczywistnionej dopiero w chwili stłumienia powstania i w sposób „jaki z góry został wskazany” $(Z, 18$; $P, 235)$, uchodzić mogły za niedwuznaczną pochwałę cara-reformatora, któremu Polska zawdzięczać miała według autora Zarysu ostateczne „pozbycie się resztek średniowiecznego ustroju społecznego", porównywalne pod względem doniosłości dziejowej $\mathrm{z}$ wcześniejszym o dziewięć stuleci wejściem „w koło narodów europejskich za pośrednictwem religii” $(Z, 18 ; P, 235)$. Cezura wyznaczona przez tak rozumiany „przewrót” nie potrzebowała żadnego kamuflażu, była bowiem w odbiorze rosyjskim nie tylko „cenzuralna”, ale i w pełni „prawomyślna”.

Dla polskiego czytelnika Zarysu - pod warunkiem, że nie uległ oficjalnej propagandzie - sprawa ta przedstawiała się jednak w zgoła odmienny sposób. Wiedział on bowiem doskonale,

3 Zob. P. Chmielowski, Zarys literatury polskiej z ostatnich lat szesnastu, Wilno 1881, s. 15, 17. Przedr. [niepełny] w: Pisma krytycznoliterackie, oprac. H. Markiewicz, Warszawa 1961, t. 1, s. 233, 235. Aby nie mnożyć przypisów, dalsze cytaty z Zarysu Chmielowskiego lokalizować będę w tekście głównym, podając $\mathrm{w}$ nawiasie okrągłym numery stron w pierwodruku $(Z)$, a tam gdzie to będzie możliwe również w pierwszym tomie Pism krytycznoliterackich $(P)$.

4 O. Miller, Powrót do życia, przeł. A. Sarachanowa, w: Okrutny talent. Dostojewski we wspomnieniach, krytyce $i$ dokumentach, wybór, wstęp, przypisy Z. Podgórzec, Kraków-Wrocław 1984, s. 135. Tłumaczenie ros. narod jako 'naród' zastępuję właściwszym w tym kontekście słowem 'lud'. 
że właściwą datę reformy agrarnej na terenie Królestwa Kongresowego stanowi nie 19 lutego/2 marca 1864 roku, kiedy to w dziewiątą rocznicę wstąpienia na tron Aleksander II podpisał swe cztery ukazy, lecz moment proklamowania dwu dekretów uwłaszczeniowych towarzyszących manifestowi władz powstańczych z 22 stycznia 1863 roku. Mówiła o tym wprost specjalna odezwa „do ludu polskiego” z końca marca 1864 roku, w której Rząd Narodowy przypominał, że już przed rokiem nadał wszystkim chłopom „wiekuistą własność posiadanych gruntów”:

Bezwstydnie [...] car moskiewski głosi wam, jakoby panowie szczęściu waszemu przeszkadzali, kiedy on panom nigdy o waszym losie stanowić nie dopuścił, aż dopiero kiedyśmy z bronią w ręku przeciwko jego zdradom i uciskowi powstali, wtedyśmy od razu całemu ludowi sprawiedliwość uczynili. [...] Car wam powiada, że wam niewypowiedzianą łaskę robi dając cudze, a raczej to, co już i bez niego jest wasze. My zaś, Rząd Narodowy, oddaliśmy swoje, a nie mamy tego za łaskę tylko za obowiązek sprawiedliwości i za ofiarę szlachty dla dobra i szczęścia wspólnego wszystkich rodaków ${ }^{5}$.

O tym, że styczniowe dekrety powstańczego rządu nie były jedynie zapowiedzią przyszłych zmian, ale rzeczywiście weszły w życie, świadczy dobitnie memoriał Mikołaja Milutina z końca 1863 roku, informujący cara, że „,buntownikom udało się [...] spełnić część swoich obietnic”, wskutek czego „powinności włościańskie [...] w samej rzeczy ustały prawie wszędzie i lud, chociaż nie dowierza trwałości tak niebywałego porządku rzeczy, przecież widocznie się traci i nie wie co robić, przywykając stopniowo do tak korzystnego położenia" ${ }^{6}$. Reforma włościańska, rekomendowana przez autora memoriału jako jedyne remedium na zaistniałą sytuację, stanowiła zatem swoistą „kontrreformę”, której prawdziwym celem była możliwie szybka pacyfikacja zbuntowanej prowincji 7 . Niechętny projektowi minister spraw wewnętrznych Piotr Wałujew skwitował całą operację słowami: „A więc dwa razy zdobyliśmy Polskę mieczem, a teraz chcemy kupić ją u polskich chłopów za cudze pieniądze" ${ }^{8}$.

Tembr wypowiedzi Chmielowskiego, na przykład gdy pisze, że kwestia uwłaszczenia była po stronie polskiej rozważana jedynie „w teorii”, a „wyraz praktyczny” zyskała dopiero w wyni-

5 Dokumenty Komitetu Centralnego Narodowego i Rzadu Narodowego 18621864, red. E. Halicz, S. Kieniewicz, I. Miller, Wrocław 1968, s. 363-367.

${ }^{6}$ Cyt. za: S. Kieniewicz, Manifest 22 stycznia 1863 roku, Warszawa 1989, s. $100-101$.

7 Zob. ibidem, s. 94-113 (rozdz. 5: „Kontrreforma carska”).

${ }^{8}$ Cyt. za: S. Kieniewicz, Powstanie styczniowe, Warszawa 1983, s. 717. 
ku decyzji podjętych przez zaborcę $(Z, 18 ; P, 235)$, współbrzmi zasadniczo z propagandowym przekazem władz okupacyjnych. Dają się w niej jednak wychwycić również tony wyraźnie z tym przekazem sprzeczne, przejęte niejako $\mathrm{z}$ dyskursu polskiego państwa podziemnego. Tak jest, po pierwsze, w przypadku zasięgu terytorialnego reformy, który przez autora Zarysu określony zostaje ewidentnie w oparciu o dekrety powstańcze, a nie jak można by się spodziewać - na podstawie aktów prawnych caratu. Chmielowski posługuje się bowiem formuła „Ruś, Litwa i Królestwo" $(Z, 17 ; P, 235)$, w której - mimo zmiany szyku nietrudno rozpoznać swoistą słowną sygnaturę władz powstańczych, mającą swój ikoniczny odpowiednik w trójherbowej pieczęci Rządu Narodowego z Orłem, Pogonią i Michałem Archaniołem. Tymczasem uwłaszczenie przygotowane na polecenie Aleksandra II przez Milutina dotyczyło wyłącznie Królestwa, które - inaczej niż wcielone bezpośrednio do Cesarstwa „Litwa i Ruś" (w oficjalnej nomenklaturze odpowiednio: Siewierozapadnyj i Jugozapadnyj $\mathrm{Kraj}^{9}$ ) - nie zostało objęte wcześniejszą ogólnorosyjską reformą $\mathrm{z}$ roku 1861 . Tę ostatnia w odniesieniu do ziem litewsko-ruskich skorygowano w odpowiedzi na dekrety powstańcze z korzyścią dla chłopów jeszcze w roku 1863, na mocy ukazów z 1/13 marca (dla guberni wileńskiej, kowieńskiej, grodzieńskiej, mińskiej i czterech powiatów guberni witebskiej - tzw. Inflant polskich) oraz z 30 lipca/11 sierpnia (dla guberni kijowskiej, wołyńskiej i podolskiej) ${ }^{\text {Io }}$. W drugim, warszawskim wydaniu Zarysu Chmielowskiego „Ruś” i „Litwa” już się w cytowanym miejscu nie pojawiły - być może za sprawą uważniejszego lub bardziej świadomego rzeczy urzędnika Warszawskiego Komitetu Cenzury ${ }^{\mathrm{II}}$.

Wprost do powstańczego Manifestuz 22 stycznia zdaje się nawiązywać z kolei ten fragment Zarysu, w którym Chmielowski, określając istotę przeprowadzonych na wsi zmian, pisze, że dzięki reformie chłop stał się „nie tylko człowiekiem, nie tylko właścicielem, ale i obywatelem kraju" $(Z, 18 ; P, 235$; podkr. - M.W.). Jeśli przyjmiemy, że ostatniego z tych tytułów nie odnosił polski krytyk do nazwy Priwislinskij Kraj, która w urzędniczym żargonie zastąpiła po stłumieniu powstania wcześniejsze „Królestwo Polskie”, uprawnione stanie się skojarzenie przytoczonej wyżej frazy z pamiętną styczniową proklamacją:

9 Zob. S. Kieniewicz, Kresy. Przemiany terminologiczne w perspektywie dziejowej, „Przegląd Wschodni” 1991, t. 1, z. 1, s. 7.

то Idem, Manifest 22 stycznia 1863 roku, s. 95-96.

II Zob. P. Chmielowski, Zarys literatury polskiej z ostatnich lat dwudziestu, Warszawa 1886, s. 14. 
W pierwszym zaraz dniu jawnego wystąpienia, w pierwszej chwili rozpoczęcia świętej walki, K[omitet] C[entralny] N[arodowy] ogłasza wszystkich synów Polski, bez różnicy wiary i rodu, pochodzenia i stanu, wolnymi i równymi obywatelami kraju. Ziemia, którą lud rolniczy posiadał dotąd na prawach czynszu lub pańszczyzny, staje się od tej chwili bezwarunkową jego własnością, dziedzictwem wieczystym. [...] Do broni więc, narodzie Polski, Litwy i Rusi, do broni! Bo godzina wspólnego wyzwolenia już wybiła, stary miecz nasz wydobyty, święty sztandar Orła, Pogoni i Archanioła rozwinięty ${ }^{\mathrm{T} 2}$.

Niezależnie od tego, czy Chmielowski, kształtując swą wypowiedź w ten a nie inny sposób, rzeczywiście zamierzał „łudzić despotę”, powiązanie obranego przez krytyka „chronologicznego punktu wyjścia” $(Z, 11)$ z kwestią uwłaszczenia sprawia, że początek projektowanego okresu literackiego przesuwa się $\mathrm{z}$ otwarcie wskazanego roku klęski powstania styczniowego na przemilczany moment jego wybuchu ${ }^{\mathrm{I} 3}$.

Warto w tym kontekście przypomnieć, że na „inicjacyjną” rolę daty 1863 w odniesieniu do swej własnej twórczości wskazywała później Eliza Orzeszkowa, która w książce Chmielowskiego (wydanej notabene nakładem jej wileńskiej oficyny) postawiona została zdecydowanie „na czele powieściopisarzów, którzy działalność swoją rozpoczęli po roku 1864" $(Z, 138)$.

Moment ten - pisała autorka Nad Niemnem - wywarł na całą przyszłość moją wpływ decydujący. [...] wzniecił we mnie pragnienie służenia Ojczyźnie według miary sił i natury moich zdolności; od jego ognia i od jego łez powstała we mnie ambicja przyniesienia choćby małej cegiełki do tego ratunkowego mostu, po którym naród przejść miał nad szeroko rozwartą pod nim otchłanią. [...] przychodziły szeregiem przedługim różne pomysły pisarskie, lecz nie było śród nich ani jednego, który by jak z pierwszego źródła, nie wytryskał z myśli o Ojczyźnie. To wszystko uczynił ze mną i we mnie rok 1863. Gdyby nie jego młot i dłuto, losy moje byłyby najpewniej inne i prawdopodobnie nie byłabym autorką ${ }^{\mathrm{I}}$.

Oglądana z takiej perspektywy „najnowsza literatura polska” mogłaby w całości jawić się jako „literatura postyczniowa” mieszcząca się w symbolicznej ramie wyznaczonej z jednej strony

I2 Dokumenty Komitetu Centralnego Narodowego i Rzadu Narodowego, s. 38; podkr. - M.W.

I3 Tą ostatnią cezurą posługiwali się, w mniej lub bardziej bezpośrednim nawiązaniu do wystąpienia Chmielowskiego, m.in. Bolesław Prus i Stanisław Tarnowski - zob. H. Markiewicz, op.cit., s. 38, 40.

${ }_{14}$ List do Mariana Dubieckiego z 4 III 1907. Cyt. za: J. Detko, Dziedzictwo powstania styczniowego w twórczości Elizy Orzeszkowej, w: Dziedzictwo literackie powstania styczniowego, red. J.Z. Jakubowski, J. Kulczycka-Saloni, S. Frybes, Warszawa 1964, s. 174-175; podkr. - M.W. 
przez Manifest z 22 stycznia, autorstwa poetki Marii Ilnickiej ${ }^{15}$, z drugiej zaś przez cykl opowiadań Orzeszkowej Gloria victis, który według pierwotnego zamysłu nosić miał tytuł „skromny i razem krwawy: 1863" ${ }^{\text {I6 }}$. Nie była to jednak, wbrew przywołanym wyżej sygnałom, perspektywa Chmielowskiego. Autor Zarysu niemal całą swoją uwagę skoncentrował bowiem nie na literackich reperkusjach polsko-rosyjskiego konfliktu politycznego, lecz na wewnętrznej walce w łonie polskich elit intelektualnych, będącej dla niego „w tej nieszczęśliwej chwili” przejawem "nadziei pełnego życia” i podstawą dla optymizmu $(Z, 10)$. I to właśnie ta walka stanowić miała wyznacznik ustanowionego za sprawą Zarysu przełomu pozytywistycznego.

Mimo że od ogłoszenia książki Chmielowskiego upłynęło już 130 lat, pojęcie przełomu literackiego pozostaje wciąż - jak zauważa Markiewicz - pojęciem „słabo zdefiniowanym”, używanym zatem $\mathrm{z}$ konieczności $\mathrm{w}$ jego znaczeniu podstawowym, tj. „wyraźnej (związanej z określoną datą) zmiany” ${ }^{17}$. Zrozumiałe, że również autor Zarysuściślejszą definicję tego pojęcia zmuszony był zastąpić odwołaniem do oczywistej dla sobie współczesnych analogii $\mathrm{z}$,obudzeniem się ducha poezji romantycznej” w latach dwudziestych XIX wieku $(Z, 25 ; P, 241)$. Zestawienie zajmującej Chmielowskiego „walki między starymi i młodymi” $(Z, 54 ; P, 267)$ z onegdajszą walką klasyków z romantykami, choć retorycznie niezwykle efektowne, było jednak zarazem bardzo ryzykowne pod względem merytorycznym $\mathrm{z}$ uwagi na rzucającą się w oczy niewspółmierność obu zjawisk. Pretensjonalności porównania nie omieszkał wytknąć w swej recenzji Sienkiewicz, pytając ze swadą:

Czyż ową lichą partyzantkę dziennikarską, którą pamiętamy wszyscy i w której prawie wszyscy braliśmy udział, można porównywać z tymi czasami, w których grzmiał Mochnacki i Mickiewicz? [...] A jeśli już taka ochota widzieć w niej przełom, to gdzie jest nowa literatura? Pokażcie ją czytelnikom i powiedzcie: oto są dzieła, oto są owoce, oto są czyny zaklęte w książki, które wypłynęły wprost z polemiki „Przeglądu Tygodniowego" z ,Kurierem Warszawskim”, „Niwy” z „Kroniką Rodzinną” i „Opiekuna Domowego” - dajmy na to $-\mathrm{z}$ „Kłosami” ${ }^{18}$.

I5 Zob. S. Kieniewicz, Powstanie styczniowe, s. 361.

${ }^{16}$ List do Aurelego Drogoszewskiego z 8 IV 1907. Cyt. za: J. Detko, „Gloria victis” Elizy Orzeszkowej, „Prace Polonistyczne” 1962 (seria 18), s. 168.

${ }_{7}$ H. Markiewicz, op.cit., s. 49-50. Według Stownika języka polskiego (red. M. Szymczak, Warszawa 1979), przełom to w pierwszym rzędzie 'zwrot, moment zwrotny w czymś, zmiana zasadnicza'.

I8 H. Sienkiewicz, Szkice literackie, t. 1, Warszawa 1951, s. 271-272 (Dzieła, red. J. Krzyżanowski, t. 45). Pierwodruk: „Gazeta Polska” 1881, nr 211-213. 
Pytanie o nowe dzieła, które stanowiłyby namacalny dowód na to, że w literaturze istotnie dokonał się pewien jakościowy przeskok, było w kontekście romantycznego precedensu jak najbardziej uzasadnione. Po ten sam argument sięgnie zresztą Chmielowski w obliczu nasilających się pod koniec stulecia tendencji modernistycznych. Napisze wówczas, że „jakkolwiek w ostatnich latach pojawiły się dążności wprost przeciwne realizmowi i pozytywizmowi, kładące nacisk na bezwzględny indywidualizm, nie ukazało się jednak jeszcze dzieło, które by zmuszało tym dążnościom przypisać znaczenie stanowcze $\mathrm{w}$ utworzeniu okresu nowego" " 9 . W podobny sposób uzasadni autor Zarysu zarzut „niewłaściwego wyboru chronologicznego punktu wyjścia”, wysunięty pod adresem swego następcy, Wilhelma Feldmana.

Tym punktem wyjścia - napisze Chmielowski w recenzji Piśmiennictwa polskiego ostatnich lat dwudziestu - jest rok 1880. Dlaczego tę datę właśnie obrał autor? Nie wyjaśnia tego nigdzie szeroko, napomyka tylko tu i owdzie, że w r. 1880 ujawniło się wiele ważnych faktów zarówno w życiu społecznym, jak literackim, ale imiennie faktów takich przytacza zaledwie parę, a w dodatku nie są one taki$\mathrm{mi}$, żeby mogły stanowić istotną datę jakiegoś nowego zwrotu ${ }^{20}$.

Nietrudno zauważyć, że wystarczyłaby jedynie zmiana daty na 1864 , by passus ten można było w całości obrócić przeciwko wcześniejszej o dwadzieścia lat książce Chmielowskiego. Rzucająca się w oczy niekonsekwencja autora Zarysu jest jednak w tym przypadku jedynie pozorna. Wynika bowiem z założonej niejednorodności kryteriów stosowanych przy wyznaczaniu punktów zwrotnych w procesie historycznoliterackim, motywowanej odmiennością wewnętrznej treści kolejnych okresów.

Tę różnicę w przypadku przełomów romantycznego i pozytywistycznego trafnie wychwycił w swej obronie Zarysu Teodor Tomasz Jeż, wytykając Sienkiewiczowi „mieszanie ze sobą rzeczy, luboć w gruncie nie sprzecznych, jak artyzm i nauka, ale oddzielnie bytujących - i oddzielne bytowanie sobie zabez-

I9 P. Chmielowski, Historia literatury polskiej, t. 3, Warszawa 1899, s. 10.

${ }^{2 \circ}$ Idem, W. Feldman o literaturze polskiej najnowszej, w: Pisma krytycznoliterackie, t. 2, s. 311. Pierwodruk: „Krytyka” 1902, z. 7-8. Notabene, gdyby przyjąć późniejsze jeszcze propozycje periodyzacyjne wyznaczające na rok 1880 początek przełomu antypozytywistycznego, uznać by trzeba, że pozytywizm „nie przeżył” nawet pierwszego wydania Zarysu Chmielowskiego - zob. T. Weiss, Przetom antypozytywistyczny w Polsce w latach 1880-1890 (Przemiany postaw światopogladowych i teorii artystycznych), Kraków 1966. 
pieczających” ${ }^{21}$. Według Jeża, „za czasów walki pomiędzy klasycyzmem a romantyzmem $[. .$.$] odbywała się [...] doniosłości$ ogromnej rewolucja, wyzwalająca artyzm spod jarzma retoryk, poetyk i wzorów”, podczas gdy w walce, „którą Chmielowski zaznacza”, chodziło „nie o formy, ale o podstawy, nie o uroki zewnętrzne, ale o istotę rzeczy - o to, co »Niwa « za dewizę była przyjęła, wypisując na czele swoim: »Wiedza - to potęga «" ${ }^{22}$. Wspomnianej różnicy charakterów obu wstępujących okresów („artyzm i nauka”) odpowiadać miała odmienność sposobu, w jaki dokonywała się implikowana przez nie zmiana. I tak romantyzm wkraczał na arenę dziejów w sposób rewolucyjny, pozytywizm zaś w drodze swego rodzaju osmozy, „nasięku - jak pisał Jeż - pierwiastków postępowych, wkradających się do literatury polskiej” dzięki „tkwieniu społeczności naszej śród Europy" ${ }^{23}$.

Zakładana z góry „naukowość” (scjentyfizm), a co za tym idzie: „nieliterackość / niepoetyckość” proklamowanego w $Z a-$ rysie nowego paradygmatu, skłoniła Jeża do szukania analogii pomiędzy relacjonowaną przez Chmielowskiego walką starej i młodej prasy a ideowym i światopoglądowym sporem wywołanym przez ogłoszenie na początku lat czterdziestych XIX wieku Mieszanin obyczajowych Henryka Rzewuskiego, przywódcy tzw. koterii petersburskiej ${ }^{24}$. Zestawienie to sytuowałoby Zarys, a przynajmniej zasadniczą dlań część pierwszą, zatytułowaną „Przekonania i dążności”, wśród takich późniejszych prac Chmielowskiego $\mathrm{z}$ historii idei raczej niż literatury, jak Liberalizm i obskurantyzm na Litwie $i$ Rusi (1815-1823) czy $Z$ dziejów postęu i reakcji u nas (druga z tych prac poświęcona została przywołanej przez Jeża polemice „Tygodnika Petersburskiego” i "Gwiazdy” 25 . Autor Zarysu, który do przełomu romantycznego odwoływał się głównie ze względu na vox populi, zdając sobie sprawę z problematyczności takiego nawiązania, opisywaną przez siebie walkę o nowe idee sam wolał łączyć $\mathrm{z}$,prądem reformatorskim wieku XVIII" $(Z, 25 ; P, 241)$.

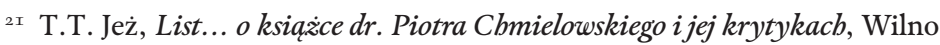
1881, s. 10; podkr. - M.W.

${ }^{22}$ Ibidem, s. 10-11.

23 Ibidem, s. 6-7. Przyimek śród zdaje się wskazywać, że w owym przenikaniu uwzględnił Jeż (zgodnie ze stanem faktycznym) również pośrednictwo Rosji.

${ }_{24}^{4}$ Ibidem, s. 6.

25 P. Chmielowski, Liberalizm i obskurantyzm na Litwie $i$ Rusi (1815-1823), „Ateneum” 1883, t. 1-2, wyd. osobne: Warszawa 1898; Z dziejów postępu i reakcji u nas, w: Prawda. Ksiażka zbiorowa dla uczczenia dwudziestopięcioletniej działalności Aleksandra Świętochowskiego 1870-1895, Lwów-Petersburg 1899, s. 94-105. 
Jak naówczas - pisał - tak i teraz wystąpiono w imię światła przeciw obskurantyzmowi, w imię tolerancji przekonań przeciw ślepemu dogmatyzmowi, w imię postępu przeciw zastojowi. Jak wówczas, tak i teraz poglądy nowe, reformatorskie pojawiały się stopniowo, występowały nader umiarkowanie względem istniejących i wiekami utrwalonych nie tyle przekonań, ile nałogów myślowych $(Z, 26$; $P, 241-242)$.

Tłumaczyłoby to poniekąd nieobecność $\mathrm{w}$ jego książce słowa „przełom”. Zwrot, którego kronikę spisywał, miał bowiem z jego punktu widzenia charakter nie tyle „kontrrewolucji”, ile „restauracji” obalonego przez romantyzm oświecenia czy - innymi słowy - restytucji myślenia oświeceniowego.

Tę swego rodzaju „reakcyjność” forsowanego w Zarysie ujęcia nader celnie wypunktował Sienkiewicz. Spod enigmatycznych peryfraz typu „kwestia sporna dotyczy środków, jakich używać potrzeba, ażeby w walce o byt nie zginąć, lecz owszem, przekazać potomkom dziedzictwo ze znacznym dorobkiem”, czy „walka w tym względzie toczy się [...] przeciw fałszywemu albo rutynicznemu pojmowaniu dróg życia społecznego" $(Z, 28$; $P, 243)$, wydobył autor Niewoli tatarskiej „kwestię klerykalizmu i antyklerykalizmu" ${ }^{26}$, najbardziej jaskrawą i zdaniem samego Chmielowskiego „najdrażliwszą” $(Z, 26 ; P, 242)$, którą ten ostatni zdecydował się umieścić na czołowym miejscu dopiero w swej syntezie historycznoliterackiej z 1900 roku $^{27}$.

W ludziach sceptycznych do wysokiego stopnia względem dogmatów i zasad przez wieki uznanych i uznawanych - konstatował Sienkiewicz - wyrodziła się wiara dogmatyczna względem... swego własnego umysłu. Wątpić we wszystko, tylko nie we własny umysł - jest to lichy objaw wątpienia i lichy objaw wiary. [...] jest to nowego rodzaju obskurantyzm, jest to nowa niewola umysłowa, jest to uwolnić się spod jarzma wielkich dogmatów dlatego tylko, by poddać się pod jarzmo małych, jest to porzucić idee a pójść w służbę do doktryn, jest to na koniec, sit venia verbo - mieć ciasną głowę. Swobodna i miłująca swoją wolność myśl potrafi wzbić się ponad to wszystko i patrzeć z zewnątrz na podobne walki bez rezultatów i bez zwycięstwa ${ }^{28}$.

To ostatnie sformułowanie wyraźnie nawiązywało do paradoksalnej konkluzji Chmielowskiego, zgodnie z którą „zwycięstwo nie przechyliło się ani na jedną, ani na drugą stronę i trud-

${ }^{26}$ H. Sienkiewicz, op.cit., s. 275.

27 P. Chmielowski, Historia literatury polskiej, t. 6, Warszawa 1900, s. 191-

192. Zob. H. Markiewicz, op.cit., s. 39.

${ }^{28}$ H. Sienkiewicz, op.cit., s. 278; podkr. - M.W. 
no nawet przewidzieć chwilę, w której by coś stanowczego zajść mogło" $(Z, 28 ; P, 243)$. W kontekście ambitnego bądź co bądź projektu periodyzacyjnego podobne stwierdzenie zakrawać mogło na kapitulację, cóż to bowiem za zwrot, którego rozstrzygnięcie odsuwa się po upływie „ostatnich lat szesnastu” w niedającą się określić przyszłość.

Niemal wyłączne skupienie się autora Zarysu na starciu „dwu walczących obozów, które [...] przezwano starym i młodym" $(Z, 28 ; P, 243)$, nie mogło nie przyczynić się do dalszej destabilizacji obranego przezeń „chronologicznego punktu wyjścia”, i bez tego - o czym była mowa wyżej - oscylującego między datami 1863/1864. Z jednej bowiem strony czytamy, że od rozpoczęcia owej walki „upłynęło już lat piętnaście” $(Z, 28 ; P, 243)^{29}$, z drugiej - że jej początek wyznaczyło ogłoszenie manifestu Aleksandra Świętochowskiego pt. My $i$ wy, który ukazał się na łamach „Przeglądu Tygodniowego" pod koniec 1871 roku $(Z, 54$; $P, 267)$. Ten rozziew, obejmujący $7-8$ lat, a więc połowę wskazanego w tytule chronologicznego zakresu pracy, w osobliwy sposób zaznaczył się również w recenzji Świętochowskiego, który od przytoczonej wiernie na samym wstępie formuły „z ostatnich lat szesnastu” przechodzi zrazu do bardziej elastycznego „przed kilkunastu laty”, by w zakończeniu pisać już o „dziesięcioletnim ruchu umysłowości naszej” i o minionym "dziesięcioleciu” ${ }^{\circ}$. Dodatkowe zamieszanie wprowadzała konwencja przyjęta przez Chmielowskiego w tytule Zarysu, licząc bowiem szesnaście lat wstecz od daty wydania książki (lub piętnaście od daty jej ukończenia) jako datę początkową omawianego okresu otrzymujemy rok 1865. Ta niezbyt wygodna konwencja powtórzona zostanie jeszcze $\mathrm{w}$ wydaniu drugim $\mathrm{z} 1886$, by $\mathrm{w}$ dwu następnych $\mathrm{z}$ lat 1895 i 1898 ustąpić miejsca bardziej przejrzystej formule: $\mathrm{Za}$ rys najnoweszej literatury polskiej, z podaniem w nawiasie dat ramowych, odpowiednio: 1864-1894 oraz 1864-1897. Niestety, przed wprowadzeniem owej korzystnej zmiany tytuł drugiego wydania: Zarys literatury polskiej z ostatnich lat dwudziestu odsyłał będzie czytelnika do jeszcze jednej daty początkowej: 1866 . Prawdziwe kuriozum stanowią jednak wprowadzane w kolejnych wydaniach aktualizacje zakresu chronologicznego walki starych i młodych, która zgodnie z nimi miała się przeciągać od

${ }^{29}$ Różnica w stosunku do tytułowego szesnastolecia sprowadza się do odstępu dzielącego czas narracji od momentu ogłoszenia drukiem.

$3^{\circ}$ A. Świętochowski, Atak lekkiej kawalerii, w: Wybór pism krytycznoliterackich, wybrał S. Sandler, oprac. M. Brykalska, Warszawa 1973, s. 128-129, 134-135. Pierwodruk: „Prawda” 1881, nr 31. 
piętnastu, dwudziestu, „mniej więcej” trzydziestu i wreszcie „z górą" trzydziestu lat ${ }^{3 \mathrm{I}}$.

Kłopoty Chmielowskiego z periodyzacją „najnowszej literatury polskiej" uznać trzeba za symptomatyczne, wskazują one bowiem na nieprzystawalność przyjętych przez niego kryteriów (nie tyle nawet teoretycznych, co wprost ideologicznych) i materii, której zarysu podjął się w swojej pracy. Demonstracyjne odwrócenie się od literatury nie mogło wszak sprzyjać uważnemu jej oglądowi, a tak właśnie - „jako przeciwieństwo względem przewagi belletryzmu" thumaczył będzie Chmielowski, aż po syntezę z końca stulecia, cechujący młodych „zapał dla wiedzy [...] przyrodniczej, ekonomicznej i filozoficznej" ${ }^{32}$. W latach poprzedzających ukazanie się pierwszego wydania Zarysu ten swoisty „redukcjonizm” w stosunku do literatury pięknej wyrażał się w formułach znacznie bardziej dobitnych, takich na przykład, jak deklaracja Juliana Ochorowicza: „zrzeczemy się raczej powiększenia skarbów naszej poezji w dobie obecnej aniżeli wzmocnienia ekonomicznych i naukowych sił kraju" ${ }^{33}$. Stanowisko to uzasadniał Ochorowicz dwa lata później w sposób następujący:

Jak niegdyś romantyzm był postępową reakcją przeciw klasycyzmowi, tak dzisiaj jest nią przeciw romantyzmowi pozytywizm - tylko nie $\mathbf{w}$ poezji - lecz $\mathrm{w}$ nauce. Pozytywizm w poezji byłby równą niedorzecznością jako romantyzm $\mathrm{w}$ polityce. Zostawmy więc co poetyckiego poezji, a co filozoficznego filozofii. Poezja musi być idealną, polityka praktyczną, a filozofia pozytywną̧34.

W opartym na zbliżonych założeniach Zarysie Chmielowskiego znalazła się zatem poezja na marginesie zasadniczego wywodu. Jak bowiem zauważa Markiewicz, „o zmianach, które nastąpiły w literaturze pięknej, mówił Chmielowski bardzo mało, skupiając uwagę na światopoglądowym i społecznym programie pozytywizmu wyrażonym w publicystyce obozu młodych" 35 .

${ }^{\text {I }}$ Cytowany fragment znajduje się w kolejnych, wskazanych wyżej edycjach Zarysu na stronach: 28, 25, 28 i 27.

$3^{2}$ P. Chmielowski, Historia literatury polskiej, t. 6, s. 194.

33 J. Ochorowicz, Romantycy i realiści, w: Publicystyka okresu pozytywizmu 1860-1900. Antologia, oprac. S. Fita, Warszawa 2002, s. 121. Pierwodruk: „Niwa” 1875 , t. 7.

34 Idem, O twórczości poetyckiej[fragmenty], w: Programyi dyskusje literackie okresu pozytywizmu, oprac. J. Kulczycka-Saloni, Wrocław 1985 (BN I 249), s. 173-174; podkr. - M.W. Pierwodruk: Lwów 1877.

35 H. Markiewicz, op.cit., s. 37. Wymowny przykład trwałości tej narzuconej przez pozytywistów optyki stanowi hasło Pozytywizm w Stowniku literatury polskiej XIX wieku, gdzie czytamy: „W dzisiejszym użyciu »pozytywizm 
Wykluczało to w praktyce zastosowanie zdroworozsądkowej dyrektywy sformułowanej w recenzji Sienkiewicza, w myśl której „historyk literatury ma za zadanie i obowiązek notować objawy prawdziwe i przyczyn szukać tam, gdzie one istnieją, nie zaś tworzyć ze szkodą przedmiotowej prawdy jakieś nowe epoki i przełomy tam, gdzie ich nie ma i nie było" ${ }^{36}$. Chmielowski, w miejsce perspektywy historyczno - czy choćby krytycznoliterackiej, przyjął odziedziczoną po oświeconych "manichejską” historiozofię, opowiadającą o odwiecznej walce „światła” i „ciemności”, której rozstrzygnięcie oddala się niczym horyzont w miarę postępowania $\mathrm{w}$ jego kierunku.

\section{MAREK WEDEMANN}

\section{Vanishing turning point. Piotr Chmielowski's difficulties with periodization of the "recent Polish literature"}

Makeshift solutions are, more often than not, the ones that tend to last longer than expected. Zarys literatury polskiej z ostatnich lat szesnastu [An outline of the literature of the last sixteen years] written by Piotr Chmielowski was designed in the author's intention as a sketch of "rather journalistic than historical features". The above is clearly indicated by the forewords written by the author to its successive four editions published between 1881 and 1898. Still, despite its lack of pretentions, the book acquired with time the status of a fully-fledged instructive approach to Polish literature of the Positivist period. A closer look at the text with regard to the proposed periodization reveals, however, a number of flaws and aporias committed by Chmielowski, particularly in establishing boundary dates of the proposed literary period. The present article attempts to prove that the source for the inaccuracies and inconsistencies of the solutions proposed in Zarys is not so much in their makeshift or the pro tem nature, but rather in the aggressively promoted ideology, represented by Chmielowski, that completely disregarded the nature of literary phenomena.

Key words: positivist breakthrough, abolition of serfdom, January uprising, strife of the old and the young press, Scientism, revival of Enlightenment thinking.

polski« oznacza przede wszystkim światopogląd panujący w 1. 1864-1895, a wtórnie także odpowiedni okres historii kultury, a zwłaszcza literatury polskiej” (Stownik literatury polskiej XIX wieku, red. J. Bachórz, A. Kowalczykowa, Wrocław 1991, s. 764; podkr. - M.W.).

${ }^{3}$ H. Sienkiewicz, op.cit., s. 273. 
Marek Wedemann - adiunkt w Instytucie Filologii Polskiej UAM. Główne nurty zainteresowań badawczych: twórczość F. Dostojewskiego, H. Sienkiewicza, S. Wyspiańskiego i ich recepcja; związki literatury i filmu. Najważniejsze publikacje: Sienkiewicz i Brandes (w: Henryk Sienkiewicz. W stulecie Nagrody Nobla, 2006); Gdzie leży Beresteczko? Kresy na mapie (w: Kresy - dekonstrukcja, 2007); Wyspiański - Dmowski: lektura waajemna (w: Narracje o Polsce, 2008); Zobrazować niewidzialne. Symbolika religijna w „Oczach szeroko zamkniętych” Stanleya Kubricka (w: Język religijny dawniej i dziś, 2009); Polonofil czy polakożerca? Fiodor Dostojewski w piśmiennictwiepolskim lat 1847-1897 (2010). 
